\title{
A Survey of Student's Media Literacy Skills in Nigerian Universities
}

\author{
${ }^{1}$ Joseph Oluchukwu Wogu, ${ }^{2}$ Christiana Ogeri Chukwu, ${ }^{1}$ Joel Chinedum Ugwuoke, \\ ${ }^{1}$ Chinyere Christiana Ugwulor-Onyinyechi and ${ }^{2}$ Chukwuemeka Ononuju Nwankiti \\ ${ }^{1}$ Department of Mass Communication, University of Nigeria, Nsukka, Enugu State, Nigeria \\ chinedu.ugwuoke@unn.edu.ng +2348035903791 \\ ${ }^{2}$ Department of Mass Communication, Alex Ekwueme Federal University, Ndufu-Alike Ikwo, \\ Abakaliki, Ebonyi State, Nigeria
}

\begin{abstract}
Information and Communication Technology (ICT) created different media platforms that require specified skills for their users. Students of mass communication are required to acquire these skills in the course of their study as undergraduates. Thus, this study investigates the level of student's acquisition of media literacy skills in Southeast Nigerian universities. The objective of this study is to determine the level of media literacy skills acquisition among undergraduate students of mass communication in Southeast-Nigeria ascertain the factors militating against undergraduate student's acquisition of media literacy skills in Southeast Nigerian universities and to proffer solutions to the identified problems. A cross-sectional survey involving students in the Departments of Mass Communication in all the 10 public universities in the Southeast was adopted. Structured questionnaire was used as instrument of data collection and technology acceptance model as framework of analysis in pursuit of the objectives. With the aid of Taro Yemane formula for determining sample size, a sample of 369 respondents was derived from a total population of 4677 students. Percentage formula and SPSS Version 20 tools (SPSS Inc., Chicago, IL) were used to analyse the data while decisions were taken based on the standard that mean difference is significant at $\geq 0.05$. Results showed that majority of the students have acquired rudimentary computer and internet knowledge and skills have not acquired substantial critical understanding competence/skills and communication abilities/skills required for effective and efficient professional practices in the current digitalised media platforms. The results further reveal that poor funding, lack of appropriate facilities, inadequate curriculum, incessant strikes, poor quality of lecturers and teaching methods are the major factors militating against undergraduate's media literacy acquisition. Appropriate and special funding intervention scheme, periodic review of education curriculum and the integration of lecturer's ICTs driven and media literacy compliance into indices for the promotion and recruitments were recommended.
\end{abstract}

$\underline{\text { Key words: Media literacy skills, ICTs, undergraduates, lecture, Nigeria, promotion }}$

\section{INTRODUCTION}

The application of Information and Communication Technologies (ICTs) to media activities and or communication, since, the, 21st century makes it imperative that students of mass communication must acquire relevant media knowledge and skills which enables them the complete their university programmes and function after graduation. These knowledge and skill which is termed media literacy skill is defined by Hobbs and Jensen (2009) as the active inquiry and critical thinking about the messages we receive and create. In line with is definition Andersen (2002) proposed that media literacy skill has to do with the thinking processes that are needed to use media contents and create new ones.
However, many scholars seem to disagree with this definition. Others view it as the ability to access media, to understand and critically evaluate the different aspects of the media and media content and to create communications in a variety of contexts (EC., 2007). Similar to this is Ding (2011)'s perception of media literacy skill as the ability to access the media, to understand and to critically evaluate different aspects of the media and media contents and to create communications in a variety of contexts. It includes all media

Although, the concise definitions of media literacy skill remain contested (Abreu et al., 2017), there seems to be an acceptance of the definition offered by the 1992 American National Leadership Conference on Media Literacy which holds that it is "the ability to access,

Corresponding Author: Joel Chinedum Ugwuoke, Department of Mass Communication, University of Nigeria, Nsukka Enugu State, Nigeria, chinedu.ugwuoke@unn.edu.ng +2348035903791 
analyse, evaluate and communicate messages in a variety of forms" (Aufderheide and Firestone, 1993). This definition which focuses on the knowledge and use of new media tools, platforms and messages (Literat, 2014), highlights four main issues involved in media literacy skill, namely: access skill, analysis skill, evaluation skill and communication skill. Media messages as used, here, refer to programmes, films, images, texts, sounds and websites found in different forms of communication. Apparently, Bunnag (2012) gave a comprehensive conceptualisation of media literacy skill thus:

"Media literacy refers to knowledge and skills that enable a recipient to understand the purpose and motive of his/her message receipt as well as those of the sender, the production and technique used by the sender to draw attention of the recipient as well as the culture, economic system and politics that may affect the creation of message meaning"

It suffice, therefore, that media literacy skill is an empowerment (Hobbs, 2010, 2017) that promotes critical engagement with messages produced by the media and the application of same to meaningfully and positively contribute to communities towards behavioural change (Buckingham, 2017; Hobbs and McGee, 2014; Hobbs, 2012; Mihailidis and the Venin, 2013; O'Neill, 2010). Thus, such literacy skills are necessary for retrieval, analysis and use of relevant archival and contemporary information for student's work such as assignments, research report, term papers, seminars, preparing for examination and for self-development. They equally enable the students to understand how media works, interrogate information accuracy, counter unfair and inaccurate representation and make better informed media choices.

These functions or responsibilities require the development or acquisition of skills in the areas of Information and Communication Technologies (ICTs), creativity and technical abilities and media platforms and environments. The students must acquire the ability to physically access media content through different delivery platforms, ability to manipulate those platforms where content might be found (the television, the mobile telephone, the computer) ability to redefine information or content to serve another purpose ability to understand what one is seeking, how to request it and what one receives, ability to evaluate critically the value or veracity of the content being received, ability to create content or communications be it through email or through audiovisual images and the ability to do all these things through available delivery platforms.
These abilities or skills are classified into technical abilities skills, critical understanding competence or skill and communication abilities or skills (Ekenna and Iyabo, 2013). Technical abilities (i.e., computer and internet skills, balanced and active use of the media such as accessing internet media, circulation and reading of books/newspapers and mobile phone subscription). Critical understanding competence or skill (i.e., understanding and distinguishing media content and their functioning such as classifying websites, media platforms and interaction system, knowledge and opinion about media and media regulations such as media concentration, sanctioning institutions for different media platforms, rules and rights applicable to media content, researcher and user rights and perception of watersheds, user behaviour which consists of exploring information and critical search for information, checks made when visiting new websites, judgement made about websites before entering personal details).

Communication abilities which consists of social relations such as user created content and creating a profile or sending message in social networking websites, citizen participation such as internet for cooperation, user centricity in online web services, citizen participation activities ever done and e-Government usage by individuals; content creation which consists of media production skill, experience creativity and user created content.

Education policy and curriculum across universities in the Southeast Nigeria particularly in the Department of Mass Communication were structured to inculcate ICTs knowledge and communication skills into students. For instance, courses like introduction to computer sciences are general courses which every student must offer in spite of one's department or faculty. Further, it has being the goal of studies in mass communication to produce media professional, yet, most of these graduates abhors media and communication activities while some others manifest high level practical illiteracy in this era of new media. Thus, this study investigates the level of media literacy skill acquisition among undergraduates of mass communication in Southeast Nigerian universities.

Objectives of the study: The main objective of this study is to examine the level of media literacy skills acquisition among undergraduate students of mass communication in Southeast-Nigeria universities. However, the specific objectives are:

- To determine the level of media literacy skills acquisition among undergraduate students of mass communication in Southeast-Nigeria 
- To ascertain the factors militating against undergraduate student's acquisition of media literacy skills in Southeast Nigerian universities

- To proffer solutions to the problems militating against undergraduate student's acquisition of media literacy skills in Southeast Nigerian universities

Research questions: The research questions derived from the specific objectives are:

- Have the undergraduate students of mass communication in Southeast Nigeria acquired high level media literacy skills?

- Has poor funding, lack of appropriate facilities, inappropriate curriculum and poor quality of lecturers and teaching methods impacted negatively on undergraduate student's acquisition of media literacy skills in Southeast Nigerian universities?

Theoretical framework: This study adopts the Davis Technology Acceptance Model (TAM) as its framework of analysis. The fundamental principle of TAM is that an active media audience or users are guided by rational decision on whether to use a given medium or not depending on the benefits each medium. Such benefits centre on the nature of the information system, its gains and advantages over others. Thus, users must acquire full knowledge of the prevailing information systems, their techniques and required skills and pros and cons in order to rationally decide the particular system to use. Thus, the technology acceptance model notes that perceived usefulness and amenability of an information system to user's skill determine the preference or choice of any.

The significance of this model to the study lies in its exposition of the fundamental requirement of media literacy skill as a determinant of media professionals choice of media platforms as primary channel of information generation, creation and dissemination in the contemporary new media era. Therefore, it provides focus for this inquiry in its effort to determine the level of acquisition of such skill by would-be media professionals. Thus, this study find it very useful to investigate the major factors militating against the acquisition of this skills by mass communication students in Southeast universities in order to forestall future crisis in the field and in the career life of the students.

\section{MATERIALS AND METHODS}

Research design: A cross sectional survey study was carried out in the universities situated in the Southeast Nigeria from May to August 2018. These universities numbering 21 , their owners and location are presented in Table 1.
Table 1: List of universities in the Southeast Nigeria

\begin{tabular}{ll}
\hline Ownership/Name & State of location \\
\hline Private universities & \\
Caritas University, Enugu & Enugu State \\
Paul University, Awka & Anambra State \\
Renaissance University, Agbani & Enugu State \\
Rhema University, Aba & Abia State \\
The University on Idemili, Alor & Anambra State \\
Godfrey Okoye University, Enugu & Enugu State \\
Coal City University, Enugu & Enugu State \\
Madonna University, Ihiala & Anambra State \\
Renaissance University, Agani & Enugu State \\
State universities & \\
Tansian University & Anambra State \\
Enugu State University of Science and & Enugu State \\
Technology, Enugu & \\
University of Nigeria, Nsukka & Enugu State \\
Imo State University, Owerri & Imo State \\
Federal University of Technology Owerri & Imo State \\
Michael Okpara Federal University of & Abia State \\
Agriculture, Umudike & \\
Abia State University, Uturu & Abia State \\
Chief Chukwuemeka Odimegwe Ojukwu University & Anambra State \\
Nnamdi Azikiwe University, Awka & Anambra State \\
Ebonyi State University & Ebonyi State \\
Federal University, Ndufu-Alike & Ebonyi State \\
National Open University of Nigeria, Enugu & Enugu State \\
\hline Nige Univen
\end{tabular}

Nigeria University Commission data base

Study location: This study adopted the department of mass communication in the ten public owned universities as its study areas. Their precise locations are Agbani, Nsukka, Owerri, Umudike, Uturu, Igbariam, Awka, Abakiliki, Ndufu-Alike and Enugu. These universities were chosen because they enjoy consolidated and guaranteed sources of funding which empower them to establish and fund relevant ICTs projects/programmes and media courses that embody the needed media literacy knowledge and skills.

Sources of data: Primary and secondary sources were explored in search of data. For primary sources, structured questionnaire which is organised on a five Likert-like options format of strongly agree, agree, undecided, disagree and strongly disagree was used to generate data from respondents. The values of these responses are as follow: strongly agree $=5$ points, agree $=4$ points, undecided $=3$ points, disagree $=2$ points, strongly disagree $=1$ point. On the other hand, in the secondary sources, relevant and accessible textbooks, journals, unpublished materials, monographs, conference and workshop papers and internet materials were explored.

Population of the study: The population for this study consists of all undergraduate students of mass communication in the ten universities studied. According to data collected from the students affairs of these institutions, a total of $(4,677)$ students registered for various programmes in their mass communication departments. 
Sample size and sampling technique: With the aid of Taro Yemane formula for determining sample size which is: $\mathrm{n}=\underline{\mathrm{N}}$

$$
1+\mathrm{N}(\mathrm{e})^{2}
$$

Where:

$\mathrm{n}=$ Sample size

$\mathrm{N}=$ Population of the study

$\mathrm{e}=$ Margin of error [which stands for 0.05 in this study]

$1=$ A constant

$$
\begin{gathered}
\text { Therefore, } \mathrm{n}=4677=4677 \\
\begin{array}{c}
1+4677(0.05)^{2} 1+4677(0.0025) \\
\mathrm{n}=4677=46771+11.6912 .69
\end{array}
\end{gathered}
$$

$\mathrm{n}=368.56$ which is approximately 369 . The study sample of 369 is divided into 10 wherein 36 respondents were selected equally in each of the universities with 9 as left-over. In each of the university, the 36 respondents were distributed equally across the four levels of study i.e., 8 in each level with 4 as left-over. In each level, the 8 respondents were randomly selected with the aid of course representative. To resolve ethical issues, the purpose of the research was explained while assurance of anonymity and confidentiality was given to them for obtaining their informed consent.

Data collection instrument: The data collection instrument employed for the study is questionnaire. The questionnaire was self-constructed and consists of two sections. Section A: this generates data on the socio demographic data of the respondents such as sex, age and level of study. On the other hand, section $B$ generates data from respondents on student's acquisition of media literacy skills and the problems associated with it.

Validity and reliability of the instrument of data collection: The 2 senior from the Department of Mass Communication, University of Nigeria Nsukka validated the instrument. Any item in the questionnaire that did not have $80 \%$ acceptance by the evaluators was discarded. Further, a test re-test method was used to measure its reliability. The 10 copies of the questionnaires were administered to similar respondents and setting at Godfrey Okoye University, Enugu in Enugu state. After an interval of 3 weeks, the questionnaires were re-administered to the same respondents. The two set of responses obtained were correlated using the pearson product moment correlation ( $\mathrm{r}$ ) and a co-efficient of reliability of 0.95 was obtained. This shows that the instrument is reliable for data collection.

Data analysis: In pursuit of central tendencies, mean and deviations, the data generated was analysed using tables, percentage formula and SPSS Version 20 (SPSS Inc., Chicago, IL). Decision were taken based on the standard that mean difference is significant at $\geq 0.05$.

\section{RESULTS AND DISCUSSION}

Percentage analysis of the Socio-demographic
data of the 320 respondents reveals male
respondents $=130(40.6 \%)$, females $=190(59.4 \%)$, age
bracket of $18-21(32.2 \%), 22-24(54.3 \%), 25-27(11.4 \%)$ and
28 and above $(2.0 \%)$. Considering the dominant position
in the literary studies which holds that the female
population is higher and that youths are increasingly
being educated and connected, the sample is an objective
one for the present study.

The results of SPSS Version 20.0 analyses of response data in Table 2 shows that responses to questions 1 which sought to find out, if mass communication students in the 10 universities studied have acquired necessary computer and internet skills reveal a total grand mean of 4.42 with a standard deviation of 0.721 . According to the tests of between-subjects effects, the mean differences of the responses show a significant difference of 0.000 whereas the mean difference should be significant at 0.05 levels. Thus, the ground means of 4.42 which represents 'Agree' in our Likert scale measure is accepted. This implies that majority of the respondents are have acquired necessary computer and internet skills as a mass communication student.

Further analysis of the responses to the statement posed to find out if the respondent scan access internet media, news circulation and read books/newspapers and mobile phone subscription reveals a grand mean of 4.21 with a standard deviation of 1.109. A tests of between-subjects effects to find out the level of difference in their responses a significant difference of 0.003 , whereas the mean difference should be significant at 0.05 levels. The pairwise comparison test carried out to determine the level of adjustment reveals no adjustment. Thus, the grand mean of 4.21 which represents 'Agree' in our Likert scale measure is accepted and implies that majority of the respondents can access internet media, news circulation and read books/newspapers and mobile phone subscription.

The result of analysis of responses to question 3 which seeks to find out, if mass communication can generate information and forward same to media platforms for publication reveals a total ground mean of 3.06 with 0.103 and 0.009 as its standard deviation and level of significance differences in their responses, respectively. 
Table 2: Results of SPSS Analyses of responses to questions

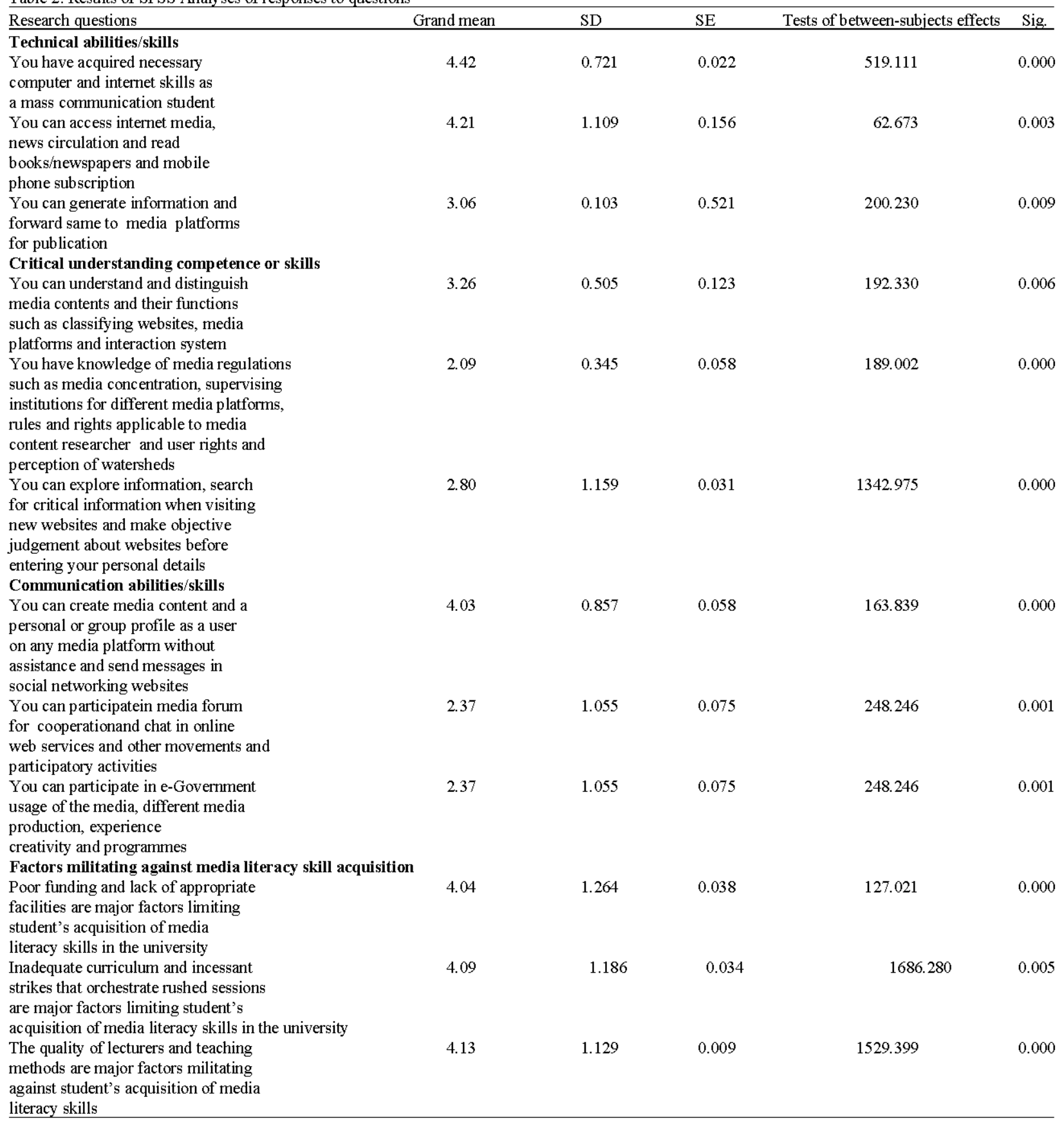

According to the tests of between-subjects effects, the mean differences of the responses show a significant difference of 0.009 whereas the mean difference should be significant at 0.05 levels. Thus, the ground mean of 3.06 which represents 'Undecided' in our Likert scale measure is accepted and implies that majority of the respondents could not explicitly say that they can generate information and forward same to media platforms for publication. Similarly in Table 2 , result of analysis of responses to question 4 which sought to find out if the respondents can understand and distinguish media contents and their functions such as classifying websites, media platforms and interaction system reveals a ground mean of 3.26 and 0.505 standard deviation whose level of significance differences are 0.006 with no adjustments required. The acceptance of the 3.26 grand mean which represents 'Undecided' in our Likert scale measures became imperative and implies that majority of the respondents 
could not equally say that they understand and can distinguish media contents and their functions such as classifying websites, media platforms and interaction system. Table 2 further shows that analysis of responses to question 5 that sought to find out if mass communication students have knowledge of media regulations such as media concentration, supervising institutions for different media platforms, rules and rights applicable to media content, author and user rights and perception of watersheds reveals a grand mean of 2.09 and standard deviation of 0.345 whose levels of differences were insignificant at 0.000 with no adjustment according to pairwise comparison. The acceptance of the grand mean of 2.09 which resents 'Disagree' in our Likert scale measures becomes imperative and implies that majority of the respondents do not have the knowledge of media regulations such as media concentration, supervising institutions for different media platforms, rules and rights applicable to media content, researcher and user rights and perception of watersheds.

Similarly, analysis of responses to question 6 which sought to determine, if the respondents can explore information, search for critical information when visiting new websites and make objective judgement about websites before entering your personal details reveals a grand mean of 2.80 with a standard deviation of 1.159 whose level of difference is insignificant at 0.000 . Therefore, the grand mean of 2.80 which represents 'Disagree' in our Likert scale measure is accepted and implies that the respondents cannot explore information, search for critical information when visiting new websites and make objective judgement about websites before entering your personal details.

Further analysis of the responses to question 7 posed to find out if the respondents can create media content and a personal or group profile as a user on any media platform without assistance and send messages in social networking websites reveals a grand mean of 4.03 with a standard deviation of 0.857 . A tests of between-subjects effects to find out the level of difference in their responses reveals an insignificant difference of 0.000 with no adjustment required. Thus, the grand mean of 4.03 which represents 'Agree' in our Likert scale measure is accepted and implies that majority of the respondents can create media content and a personal or group profile as a user on any media platform without assistance and send messages in social networking websites.

However, analysis of responses to question 8 which sought to determine, if the respondents can participate in media forum for cooperation and chat in online web services and other movements and participatory activities, reveals a grand mean of 2.37 with a standard deviation of
1.055 whose level of difference is insignificant at 0.000 . Therefore, the grand mean of 2.37 which represents 'Disagree' in our Likert scale measure is accepted and implies that the respondents cannot participate in media forum for cooperation and chat in online web services and other movements and participatory activities.

Results of analysis to question 9 which seeks to determine, if the respondents can participate in e-Government usage of the media, different media production, experience creativity and programmes and the conclusions reached thereof is the same with that of question 8. Thus, students cannot participate in e-Government usage of the media, different media production, experience creativity and programmes.

Analysis of responses to question 10 which sought to determine, if poor funding and lack of appropriate facilities limit student's acquisition of media literacy skills in the university, reveals a grand mean of 4.04 with a standard deviation of 1.264 whose level of difference is insignificant at 0.000 . Therefore, the grand mean of 4.04 , which represents 'Agree' in our Likert scale measure is accepted and implies that poor funding and lack of appropriate facilities limit student's acquisition of media literacy skills in the university.

Similarly, analysis of responses to question 11 that interrogated whether curriculum and incessant strikes that orchestrate rushed sessions limit student's acquisition of media literacy skills in the university reveals a grand mean of 4.09 with a standard deviation of 1.186 whose level of difference is insignificant at 0.005 . Therefore, the grand mean of 4.09 which represents 'Agree' in our Likert scale measure is accepted and implies that the inappropriate curriculum and incessant strikes that orchestrate rushed sessions limit student's acquisition of media literacy skills in the university.

Equally, analysis of responses to question 12 that investigated whether the quality of lecturers and their teaching methods are major factors militating against student's acquisition of media literacy skills reveals a grand mean of 4.13 with a standard deviation of 1.125 whose level of difference is insignificant at 0.000 . Therefore, the grand mean of 4.13 which represents 'Agree' in our Likert scale measure is accepted and implies that the quality of lecturers and their teaching methods also constitute a challenge to student's acquisition of media literacy skills.

The results of data analysis indicated that the respondents have acquired a fair but limited media literacy skill. According to the results, majority of them have the technical abilities/skills (such as computer and internet literacy and accessing and circulating online information, etc.) to engage the media. This finding affirms earlier 
findings by scholars which hold that greater number of Nigerians particularly undergraduates is increasingly being connected to internet/online social networks activities. For instance Adeoye and Adeoye (2017), Adetinmirin, Salaam (2007), Thomas (2004) among others. It is pertinent to note that the acquisition of these skills is a general prerequisite for all computer and internet users. They are not exclusive for mass communication or media professionals alone.

However, this study as exhibited in the results of analysis above observes that undergraduates of mass communication in Southeast Nigerian universities lack or have not acquired relevant critical understanding competence or skills to engage the media. Majority of them cannot understand and distinguish between different media contents and their functions and media regulations/rules and sanctioning/supervising institutions, neither can they search for critical information when visiting new websites and make objective judgement about websites before entering your personal details. These skills are exclusive for media professionalism. Thus, this observation of none acquisition of relevant critical understanding competence or skills is critical because as professionals to be they cannot perform their responsibilities effectively and efficiently without these skills.

The results of the data analysis equally reveal that the respondent's acquisition of communication abilities/skills which is the main frame of the media is very low. Although, majority of the respondents acknowledged that they can create media content and a personal or group profile as a user on any media platform without assistance and send messages in social networking websites they lack the necessary skills to participate in media forum and e-Government usage of the media, engage in different media production, lack skills for creativity and programming. These are essential components of media globalisation and the new media. Thus, if this scenario is not addressed before their graduation, they shall be irrelevant in the 21 st century media production, circulation and consumption.

However, the results of the analysis revealed the major factor that caused and are sustaining the observed media literacy skills deficiencies among mass communication students in Southeast Nigerian universities. These factors are poor funding and lack of appropriate facilities for teaching and learning media technologies and skills, inadequate curriculum and incessant academic staff strikes that limits both the thematic scope and period of covering the curriculum and poor quality of media technology lecturers and teaching methods. These observations are in line with earlier findings made by different scholars. For instance, harnessing ICT tools and services requires vision, new roles and relationships and skills/competence (Achimugu et al., 2009) while majority of the university lecturers (those in department of mass communication inclusive) who belong to the senior cadre are either ICTs non-compliance or indifferent to the new media technologies (Kpolovie and Awusaku, 2016; Albirini, 2006). It is therefore, certain that students under their tutelage should not acquire such skills which they were not taught expect on personal or out of school efforts. The implication of this observation is that most of the university administrators in Nigeria have not taken concrete steps to address in site of research reports and recommendations.

Similarly, the findings were supported by Anene and Odumih (2014), Jegede (2014) and Idowu and Esere (2013) earlier findings which indicted government's lack of interest in providing ICTs facility and poor funding as part of problems universities are encountering. Poor funding of higher education in Nigeria has being a perennial problem that tends to constitute an unending crisis between the Academic Staff Union of Nigerian Universities (ASUU) and the Federal Government. In short, ASUU embarked on an indefinite strike, since, November 2018 to protest under-funding and lack of government interest in the structural development of institutions of higher learning. This has serious implication for higher education in general and media literacy skill's acquisition in particular.

\section{CONCLUSION}

This study investigated the level of media literacy skills acquisition among students of mass communication in Southeast Nigerian universities. The study observes that majority of the students of mass communication in these universities have acquired rudimentary computer and internet knowledge and skills which any other person (including none students need in the modern global village). However, they have not acquired substantial Critical understanding competence/skills and communication abilities/skills required for effective and efficient professional practices in this new media or digitalised media era. The study further observed that fundamental educational and institutional factors are responsible for this deficiency. These factors include poor funding, lack of appropriate facilities for teaching and learning, inadequate curriculum, incessant strikes, poor quality of media technology lecturers and teaching methods. 


\section{RECOMMENDATION}

The study recommends appropriate and special funding intervention scheme for universities in Southeast Nigeria and others in general. Stakeholders in higher education in the region should organise seasonal fund raising projects to philanthropist for the funding and equipping of ICTs centres and programmes in the universities. Further, government should increase the annual appropriation for the education sectors, particularly higher institutions. These will help to eliminate the problems of poor facilities, incessant strikes and poor funding of media literacy programmes.

In addition, universities should adopt the method of reviewing their education curriculum periodically, at least every 5 years, in order to integrate developments and dominant research findings and recommendations in all the disciplines of study particularly in mass communication. This will eliminate the problem of inadequate or limited thematic scope that hinders the teaching and learning of emerging issues. It will also pressure lecturers into updating their knowledge for purposes of advancing education. Within this school of thought lay the integration of computer, internet and media literacy compliance as indices for the promotion, appointments and recruitments of lecturers in mass communication department.

\section{ACKNOWLEDGEMENT}

We thank the students for bringing out their time to complete the questionnaires.

\section{REFERENCES}

Abreu, B.S.D., P. Mihailidis, A.Y.L. Lee, J. Melki and J. McDougall, 2017. Arc of Research and Central Issues in Media Literacy Education. In: International Handbook of Media Literacy Education, Abreu, B.S., P. Mihailidis, A.Y.L. Lee, J. Melki and J. McDougall (Eds.)., Taylor \& Francis, New York, USA., ISBN:978-1-138-64549-3, pp: 1-16.

Achimugu, P., O. Oluwagbemi, A. Oluwaranti and B. Afolabi, 2009. Adoption of information and communication technologies in developing countries: An impact analysis. J. Inform. Technol. Impact., 9: $37-46$.

Adeoye, A.A. and B.J. Adeoye, 2017. Digital literacy skills of undergraduate students in Nigeria universities. Lib. Philos. Pract., 1: 1-23.

Albirini, A., 2006. Teachers attitudes toward information and communication technologies: The case of Syrian EFL teachers. Comput. Educ., 47: 373-398.
Andersen, N., 2002. New media and new media literacy: The horizon has become the landscape-new media are here. Center for Media Literacy (CML), Malibu, California, USA. http://www.medialit.org/ reading-room/new-media-and-new-media-literacy

Anene, J.N. and I.T. Odumih, 2014. Problems and prospects e-Learning in Nigeria universities. Intl. J. Technol. Inclusive Educ., 3: 320-327.

Aufderheide, P. and C.M. Firestone, 1993. Media Literacy. Aspen Institute, Washington, USA.,.

Buckingham, D., 2017. Fake news: Is media literacy the answer?. Blog, USA. https://davidbuckingham. net $2017 / 01 / 12 /$ fake-news-is-media-literacy-the-ans wer/

Bunnag, K., 2012. Factors affecting media literacy of early teenagers. World Acad. Sci. Eng. Technol. Intl. J. Soc. Behav. Educ. Econ. Bus. Ind. Eng., 6: 2599-2603.

Ding, S., 2011. The European Commission's Approach to Media Literacy. In: Media Literacy: Ambitions, Policies and Measures, Livingstone, S. (Ed.). London School of Economics and Political Science, Holborn, London, UK., ISBN:978-2-9601157-2-7, pp: 5-7.

EC., 2007. Media literacy: Do people really understand how to make the most of blogs, search engines or interactive TV?. European Commission, Brussels, Belgium. http://europa.eu/rapid/press-release_IP -07-1970_en.htm?locale $=$ en.

Ekenna, M. and M. Iyabo, 2013. Information retrieval skills and use of library electronic resources by university undergraduates in Nigeria. Inf. Knowl. Manage., 3: 6-14.

Hobbs, R. and S. McGee, 2014. Teaching about propaganda: An examination of the historical roots of media literacy. J. Media Literacy Educ., 6: 56-67.

Hobbs, R., 2010. Digital and Media Literacy: A Plan of Action. The Aspen Institute, Washington, USA., ISBN:9780898435351, Pages: 64.

Hobbs, R., 2012. The blurring of art, journalism and advocacy: Confronting 21 st century propaganda in a world of online journalism. J. Law Policy, 8: 625-637.

Hobbs, R., 2017. Teaching and learning in a post-truth world. Educ. Leadersh., 75: 26-31.

Idowu, A.I. and M. Esere, 2013. ICT and higher educational system in Nigeria. Educ. Res. Rev., 8: 2021-2025.

Jegede, A.E., 2014. Cyber fraud, global trade and youth crime burden: Nigerian experience. Afro Asian J. Soc. Sci., 5: 1-21.

Kpolovie, P.J. and O.K. Awusaku, 2016. ICT adoption attitude of lecturers. Eur. J. Comput. Sci. Inf. Technol., 4: 9-57. 
Literat, I., 2014. Measuring new media literacies: Towards the development of a comprehensive assessment tool. J. Media Literacy Educ., 6: 15-27.

Mihailidis, P. and B. Thevenin, 2013. Media literacy as a core competency for engaged citizenship in participatory democracy. Am. Behav. Sci., 57: 1611-1622.

O'Neill, B., 2010. Media literacy and communication rights. Intl. Commun. Gaz., 72: 323-338.
Salaam, M.O., 2007. Options for access to journals, print, CD-ROM, on-line in a Nigerian agricultural university library. Samaru J. Inf. Stud., 7: 24-27.

Thomas, N.P., 2004. Information Literacy and Information Skills Instruction: Applying Research to Practice in the School Library Media Center. 2nd Edn., Libraries Unlimited, London, England, UK., ISBN:9781591580812, Pages: 225. 